\title{
'Second-wave' black feminist periodicals in Britain
}

Article

Accepted Version

Thomlinson, N. (2017) 'Second-wave' black feminist periodicals in Britain. Women: a cultural review, 27 (4). pp. 432-445. ISSN 1470-1367 doi:

https://doi.org/10.1080/09574042.2017.1301129 Available at https://centaur.reading.ac.uk/69476/

It is advisable to refer to the publisher's version if you intend to cite from the work. See Guidance on citing.

To link to this article DOI: http://dx.doi.org/10.1080/09574042.2017.1301129

Publisher: Taylor \& Francis

All outputs in CentAUR are protected by Intellectual Property Rights law, including copyright law. Copyright and IPR is retained by the creators or other copyright holders. Terms and conditions for use of this material are defined in the End User Agreement.

\section{www.reading.ac.uk/centaur}

\section{CentAUR}

Central Archive at the University of Reading

Reading's research outputs online 


\title{
'Second wave' Black Feminist Periodicals in Britain
}

\section{NATALIE THOMLINSON}

\begin{abstract}
This article offers a long overdue exploration of black feminist periodicals in the UK during the period of second wave feminism. In it, I examine four feminist periodicals - FOWAAD, Speak Out, We Are Here, and Mukti - in order to trace the development of black feminism in Britain and to investigate the extent to which black feminist periodicals in the UK became key sites for the development of a black feminist political critique that was aimed at three sites: the (white) feminist movement; the racist British state; and patriarchal structures within migrant communities. Insisting upon the interconnected nature of gendered, race and class oppression in a manner that foreshadowed many contemporary theoretical developments around the politics of intersectionality, these periodicals provide vital insights into the black women's movement and its complicated relationship to larger radical black movement and the concept of 'political blackness'.
\end{abstract}

\section{Keywords}

Black women, feminism, intersectionality, periodicals.

\section{Biographical Note}

Natalie Thomlinson took her PhD from the University of Cambridge in 2013 and is currently Lecturer in History at the University of Wolverhampton. Her book, Race, Ethnicity and the Women's Movement in England, 1968-1993, was published by Palgrave Macmillan in 2016.

\author{
Contact Details \\ University of Wolverhampton \\ Faculty of Social Sciences \\ MC Building \\ City Campus North \\ Wolverhampton \\ WV1 1LY \\ +44(0)1902323517 \\ natalie.thomlinson@wlv.ac.uk
}




\section{Second wave black feminist periodicals in Britain}

This article is an exploration of black feminist periodicals in the UK during the period of second wave feminism, which began in Britain in the late 1960s. Whilst only ever gaining a limited audience, black feminist periodicals in the UK became focal points for the development of black feminist theory, as well as venues at which a specifically black female political subjectivity was first developed and articulated. These periodicals, which were sites of contestation within the black women's movement, delivered a political critique that was aimed at three institutional targets: the (white) feminist movement, the racist British state, and patriarchal structures within migrant communities. They insisted on the interconnected nature of gendered, race and class oppression in a manner that foreshadowed many contemporary theoretical developments around the politics of intersectionality. This article will focus on four specific periodicals - FOWAAD, Speak Out, We Are Here, and Mukti - in order to trace the development of black feminism in Britain and to understand the place of periodical culture within it.

As Maria DiCenzo, Lucy Delap and Leila Ryan have argued, there is a key place for the use of periodicals in feminist research (2011). Much feminist theory, at least in England, remained unpublished during the 1970s and 1980s, creating a space in which periodical culture thrived. Particularly during the late 1970s through to the mid-1980s, when the number of national feminist conferences in the UK drastically reduced, periodicals became the most significant arena for internal feminist debate, and it was during these years that the number of self-published feminist periodicals was at its height. These periodicals both reflected and drove forward feminist debate, and were often ideologically heterogeneous, representing a range of viewpoints rather than a 


\section{Black Feminist Periodicals}

single theoretical line. Periodicals also provide us with useful access to the responses of readers, offering an indication of how particular debates and theoretical developments were received. At the same time, they reveal the reciprocity between those who produced these periodicals and their readers (although with smaller publications there was a great deal of overlap between those two groups).

These newsletters and journals were also found within the black women's movement, though on a much smaller scale, with local newsletters being found only in London. If, using Nancy Fraser's well-known formation, we think about the feminist press as addressing a 'subaltern counterpublic' (which, in her words, are 'parallel discursive arenas where members of subordinated social groups invent and circulate counterdiscourses to formulate oppositional interpretations of their identities, interests and needs'), then black feminist periodicals were addressing a counterpublic of a counterpublic, carving out a space through which black feminists could contest racist hegemonic norms in general, and criticize the (white) women's movement in particular (Fraser 1992: 116). Indeed, as we shall see, the very utility of feminism to black women was questioned several times in these periodicals, and the women's liberation movement criticized as racist.

Periodicals also served to build and shape the movement, to bring together individual activists, many of whom had never met each other, into a collective (if contested) feminist identity. In other words, periodicals gave abstract movements material form; in some sense, they made movements by providing a focal point for debate and allowed for movements to be understood as coherent entities. Within periodicals feminist aims could be formulated and articulated publicly. Drawing on Francesca Polletta and James Jasper's work on collective identities, Maria DiCenzo has argued that 'Periodicals functioned as one medium $[\ldots]$ through which these [feminist 


\section{Black Feminist Periodicals}

values] could be articulated, communicated and responded to' (DiCenzo, Delap and Ryan 2011: 49). They provided their readership with access to an 'imagined community', allowing readers to become part of the women's movement through the act of reading; as Sidney Tarrow has argued 'print, association and coalitional campaigns of collective action build solidarity among larger numbers of people and help to diffuse movements to new publics' (Tarrow 1993: 52).

\section{The Black Women's Movement in Britain}

Black British women's activism was a highly distinctive social movement that drew from several different radical traditions. As this article will examine, the black women's movement harnessed aspects of 'mainstream' feminism with growing regularity throughout the 1980s, but its origins in black radicalism meant that it remained distinct from the (largely white) women's liberation movement in a number of key ways.

The term 'black' was used politically by activists during this period to include all those who were colonized (rather than just those of African or Afro-Caribbean descent), contingent on the supposedly shared experiences of Afro-Caribbean, African, and Asian immigrants to Britain in the post-war era. Despite the widespread use of the term during the 1970s and into the 1980s - when it was embraced by each of the four periodicals examined in this article - 'black', as a political formulation, became a growing source of contention, especially amongst Asian writers who complained that the term hid their distinct experiences within postcolonial society (Modood 1988). This was of particular significance when it came to the formation of the Asian women's magazine Mukti, and how it and its readers constructed their ethno-political identities. As Nydia Swaby has argued in a recent Feminist Review article, political blackness was always contested within the black women's movement, with significant debates about 


\section{Black Feminist Periodicals}

who was entitled to organize under its banner (Swaby 2014). Nevertheless, almost all politically active black women during the 1980s were unwilling to abandon political blackness as a concept, due to its perceived usefulness in developing a politics of solidarity across a variety of ethnic minority communities. As Swaby argues, the attempts of black feminists to develop a gendered political blackness constituted a core part of their mission.

The first black women's groups in Britain had their roots in the Black Power movement. Whilst not explicitly feminist, the politics of the black movement, like most leftist politics, did at least pay lip service to the equality of women, though often this was not borne out by the practice of the men in such organisations (Bryan et al. 1985; Sudbury 1998). The Marxist-oriented politics of British black power groups (Wild 2008) heavily influenced the analysis of black women's politics in the UK, and resulted in an analysis that, initially, understood black women's oppression as a consequence of their economic position under capitalism. Groups such as the Organisation of Women of African and Asian Descent (founded 1978) and Brixton Black Women's Group (formed 1973) were different from early white feminist formations in that they were focused on the place of women within black radical struggles, rather than on examining and theorizing women's subjective experiences of male domination, which had tended to shape the intellectual agenda of the UK women's liberation movement in the 1970s. However, during the late 1970s and early 1980s increasing numbers of black women became involved in groups that were mainly attended by white women, and this, along with the coalescence of the black women's movement, led to the formation of a trenchant critique of white feminist theory and practice.

This critique suggested that the concerns of white feminists did not necessarily translate to the needs of black women, that white feminists did not understand how 


\section{Black Feminist Periodicals}

racism profoundly structured the lives of black women, and that black women were, to all purposes, invisible to white feminists. Black women argued that true liberation for all women could only be achieved if all facets of women's oppression - including race and class as well as sex - were taken into account (Amos and Parmar 1984). As such, British black feminism demanded not just a space within feminist discourse, but a fundamental transformation of the terms of the debate. In many respects, this foreshadowed contemporary debates on intersectionality, a term first coined by Kimberlé Crenshaw (1989). Whilst, as this article will explore, there are some differences in the way that contemporary black feminists today understand how these categories combined to produce oppression, it is clear that the black women's movement was, from the beginning, shaped by the desire to expose how class and race affected the ways in which gender was experienced by women. The attempt to understand these connections, and to elaborate on them, is constantly present in the periodicals explored in this article.

It is important to note that race was an issue that was being debated within all (or at least most) of the feminist periodicals in Britain, and not just the periodicals discussed in this journal article. Indeed, the editorial collective at Spare Rib was changed in 1984 in order to better represent 'women of colour' (the term used by the collective themselves), following the success of a special 'Black Women's Issue' in October 1983. Debates around race were often a central focus of that magazine in the 1980s, and were often bitter. Likewise, the prominent periodical Feminist Review saw a series of debates on these issues and also moved to recruit more black women to its collective, most notably in its black women's special issue in 1984, 'Many Voices, One Chant' (Feminist Review 17, 1984). Yet, despite the apparent 'mainstreaming' of race in UK feminism during the 1980s, the bitterness of some of these arguments served to 


\section{Black Feminist Periodicals}

underline for black feminists the importance of retaining their own autonomous space in which such issues could be discussed between other black women; indeed, We Are Here proclaimed on its cover that it was for 'black women only'.

\section{The Periodicals}

I now want to move on to discuss the content of the newsletters themselves, and to think more specifically about what these periodicals can tell us about the black women's movement, and the role of periodicals in feminism.

Speak Out and FOWAAD were the first black feminist periodicals to be published in Britain in the 1970s. Both based in London, they were published irregularly and were produced by Brixton Black Women's Group and the Organisation of Women of African and Asian Descent. No circulation figures exist, but given the size of the black women's movement and the tiny numbers of women who were actively involved in making these periodicals, it seems unlikely that they numbered more than a few hundred. Both journals relied on the contributions of members of their parent groups to write for them, and, like much radical media of the 1970s, were more focused on political messages than production values, making sparing use of photographs and illustrations, in favour of densely packed text. Speak Out, in particular, functioned as a theoretical journal in which various political positions were debated and expounded, particularly regarding issues such as anti-imperialism, anti-capitalism and anti-racism. One typical article argues the following:

[A]s black women we are strongly influenced by the knowledge that our countries of origin, the so-called 'Third World', having been actively underdeveloped by colonialism (a part of capitalism) is even now being raped and pillaged under the 


\section{Black Feminist Periodicals}

stranglehold of imperialism (yet another, and to us very relevant, aspect of capitalism). (Speak Out 4, undated)

Indeed, as this suggests, much of the material was not overtly feminist, but focused on issues pertinent to the black community as a whole, and was itself representative of the origins that the black women's movement had in the radical black movement, rather than the feminist movement. Such densely intellectual material was unlikely to win new recruits to the cause; of all the periodicals reviewed in this article, Speak Out is least interested in developing a dialogue with its readership, or in appealing to black women outside the movement. It did, however, provide a vital arena in which theories of oppression could be developed.

Like the black women's movement in the 1970s, both FOWAAD and Speak Out were focused on campaigns and an indictment of the racism of the British state, rather than discussions about the politics of the personal and patriarchy. Again, much of this theorizing placed the oppression of black women squarely within a Marxist framework. Such politics are well illustrated in the editorial of the fourth edition of FOWAAD from February 1980:

As Black People we were brought here to do the low-paid, meanial[sic] work which white workers refused to take. As Women, our labour has always been both under-paid and under-valued. It is therefore hardly surprising that BLACK WOMEN have been the first to lose our jobs when firms have decided to reduce their work force in the interest of profits. Our situation has been further aggravated by the closure of so many nurseries, forcing us back into the home to do unpaid labour which Capitalism relies on (FOWAAD 4, 1980) 
This economically determinist emphasis on the class roots of black women's oppression demonstrates the importance of not reading such theorizing as being identical to contemporary feminist theorizing around intersectionality. This passage clearly demonstrates the more central place of Marxism in black feminist discourse during the 1970s and 1980s. Nevertheless, the linking of race, class and gender in this passage does foreshadow intersectionality in important ways, and suggests that it is unlikely that such analytical developments would have occurred without the intellectual roots and preoccupations of black British feminism in the 1980s.

These periodicals also aspired, importantly, to function as conduits of news and information, as well as to provide a forum for the discussion of black feminist issues. FOWAAD was somewhat more news oriented than Speak Out (though was also heavily theoretical in places), and both FOWAAD and Speak Out also featured reviews of books and creative features such as poetry. As the first issue of $F O W A A D$ proclaimed:

we hope that sisters will relate to the contents of this newsletter so much that you will begin to see it as your paper - for it is your letters and articles, your news and reviews, your ads, cartoons and poems, which will make FOWAAD into the genuine mouthpiece of Black women in Britain.(FOWAAD 1, 1979)

The extent to which it achieved these aims is questionable. Certainly, FOWAAD seemed to struggle to find contributors and to encourage black women around the country to see it as 'their paper', as the fact that FOWAAD only ran to seven issues perhaps demonstrates. These 'imagined communities' of readers were indeed sometimes all too imaginary. This was a problem that periodicals across the country ran into as they 


\section{Black Feminist Periodicals}

attempted to sustain regular publication, pointing to the limited number of readers and writers that such magazines and newsletters could rely on, as well as the fact that many black women were perhaps less likely than their white counterparts to have the time and economic resources to engage with and contribute to feminist periodicals.

The We Are Here newsletter was a small publication founded after a conference of the same name - the first dedicated black feminist conference ever held in Britain had taken place in London in May 1984. This newsletter was a reflection of a general shift within the black women's movement towards a more recognizably feminist politics - one that focused more closely on the politics of patriarchy and the personal. This is mirrored in the content of the We Are Here newsletter. Unlike Speak Out and FOWAAD, We Are Here tended to concentrate on the experiences of black women rather than on the wider issues affecting the black community. We Are Here demonstrated a greater concern with issues such as sexuality, incest and health - topics which also preoccupied white feminists, and which, within the newsletter, were covered in a manner that was overtly influenced by the women's liberation movement. As this focus on a politics of embodiment may suggest, striking also in We Are Here was the attention paid to subjective experience as well as to 'objective' political analysis. To evoke that most well known of white feminist slogans, the personal was becoming increasingly political within black women's circles in the 1980s. Importantly, there was a growing willingness to critique black men as perpetuators of patriarchal oppression, an analysis that was often evaded by black feminists in the 1970s who did not wish to be seen to be criticizing immigrant communities in public. In addition, We Are Here dedicated more coverage to lesbian issues than Speak Out and FOWAAD, where space was rarely given over to questions of sexuality due to the complexity of lesbian politics 


\section{Black Feminist Periodicals}

within the black community, which was often socially conservative on matters of gay rights (Sudbury 1998).

Nevertheless, despite the fact that in some senses we see black feminism move closer to white feminism in the pages of We Are Here, the perceived failures of white feminists to take into account the effects of race and class as well as gender led to a continuation of the critiques seen in both FOWAAD and Speak Out. Perhaps most thoroughgoing of these was a piece published in 1985 that, in line with black American thinkers such as Alice Walker (1983), rejected the very term 'feminism' in favour of 'womynism' (more usually spelt as 'womanism'):

Fundamental economic and social change is a prerequisite of any real change for the majority of the people. Black Womynism takes into account our oppression as black people in general and as black womyn in particular. The majority of black womyn are working -class (or those working on the land) and this must influence the identity of all black womyn [ ...] The ideology on which Black Womynism is based demands an understanding of racism, sexism, classism, and hetero-sexism. (Lee and Black, We Are Here 5, 1985)

That said, this rejection of 'feminism' as a term was always controversial. Other black women wished to reclaim it. One woman wrote to We Are Here in response to this article:

I was bemused and disturbed to read what appears to be the current debate amongst some black women i.e. should we call ourselves feminists? My instance response is, why not? After years of asserting your feminist ideology and politics, and 


\section{Black Feminist Periodicals}

developing a black feminist that is based on our experience of oppression, surely we need to concentrate on furthering the development of our ideology and making feminism available to more black women, rather than regressing by invisibilising ourselves and our politics (We Are Here, unnumbered,1986).

We can see the ideological diversity at play in these periodicals. We Are Here stuttered to a finish in mid 1986 having produced around ten issues but, like so many other periodicals of its type, finding it difficult to get enough resources to put out the magazine. It was then unexpectedly revived by a group of women from Leicester, Coventry, Birmingham, Nottingham, and Sheffield after a meeting organized by Leicester women in late 1987 who had felt that the magazine was becoming too 'London-based' (a common complaint in black feminist circles). This publication was materially different from its first incarnation, resembling a magazine rather than a newsletter in format, and having more professional production values (though still being very far from the standard issue 'glossy' women's magazine, or even Spare Rib). Given these substantial alterations to the periodical, both in terms of its format and geographical locus, contributors to We Are Here were moved to point out the links to its earlier incarnation, and the similarities of its aims:

Welcome to the first edition of the 'We are here' magazine. In fact it is not actually the first edition because the 'We are here' newsletter has been around London since July 1984.

The We Are Here newsletter came out of the first Black Feminist Conference, 'We Are Here', the newsletter then became an ongoing space in which Black women could express their desires, anger or happiness with each other, through the newsletter. (We Are Here [new series] 1, 1988) 


\section{Black Feminist Periodicals}

Nevertheless, this new project came to a premature end after only four issues, once again stymied by the problems of getting people to contribute to the magazine. A couple of rather passive aggressive-editorials underlined the issue:

Last issue we started off by apologizing for the later arrival of issue no. 2 . This time, no apology. Even though we are late we waited for you to send us in letters, articles etc. etc. but as you can see only a few responded. [...] What do you think? You probably won't reply anyway! We need women to write for us, tell us what is happening out there. We also need more women to join the collective. We Are Here [new series] 3 ,1988)

Issue number four started off with a broadly similar editorial. This spoke to a larger issue of the unsustainably small audience for such publications, as well as the straitened conditions that the black women's movement found itself in towards the end of the 1980s.

Mukti faced similar challenges. In certain respects, it was the most substantial of these publications. Published in the mid 1980s and supported by a grant from the Greater London Council, Mukti was an ambitious publication that was published in six languages - English, Urdu, Hindi, Gujurati, Bengali and Punjabi - in order to try and reach as many readers as possible, given that not all Asian female migrants spoke fluent English. However, as the last issue revealed, the resources that this time-consuming translation required was possibly detrimental to the success of the magazine (Mukti 7, 1987; Forster 2015). Despite these laudable intentions, the extent to which Mukti truly managed to reach a diverse audience is unclear: the majority of letters to the magazine 


\section{Black Feminist Periodicals}

seem to suggest that many of their readers were already political. Again, no circulation figures are in existence, but given the relatively small nature of the team involved in producing Mukti, it seems unlikely that these figures were in anything more than the hundreds, though again, letters from the readership suggest that the magazine was read in a relatively wide range of areas across the country.

Like the other black feminist periodicals discussed in this article, Mukti focused both on the racism of the British state and campaigns around associated issues, including immigration law. This produced a magazine that had, at times, a rather educational tone: as Laurel Forster has argued in her recent work on Mukti in Magazine Movements (2015), Mukti attempted to fulfill a pedagogic role to its readers that sat somewhat uneasily with its attempts to create a non-hierarchical relationship between the producers and readers of the magazine. However, like We Are Here, Mukti also contained many pieces from British-Asian women discussing the struggles of their own lives in a style that feels reminiscent of the consciousness-raising sessions more associated with white feminists of the early 1970s. Issues such as relationships, sex, the body, and family life were all addressed in ways that were deeply critical, for example, of the lack of female pleasure in sex (issue 3 was entirely devoted to sexuality) and the patriarchal structure of the Asian family. Lesbianism was also written about extensively; and the ways in which these issues were experienced in different ways by Asian women as opposed to white women, was also discussed. One lesbian Asian woman criticized the expectation on her by white feminists to be 'out' all the time, given the cultural pressures she felt:

Hiding - from one's own parents, one's friend's parents especially if they are Asian is a far worse problem than for white women. Something a lot of 


\section{Black Feminist Periodicals}

white radical feminists do not seem to realise. Your family is your culture.

(Mukti 3, 1984)

Set against the putative conservatism of the Asian community, Mukti functioned as a 'safe space' in which matters of sexuality could be discussed openly. It afforded readers the opportunity to 'come out', as well as to critique their communities, without the fear of reinforcing damaging cultural stereotypes. In this way, the magazine worked towards fulfilling personal, as well as political, needs. To some readers, it furnished them with the sense that they were 'not alone', as evidenced by this letter from a 15-year-old muslim feminist:

\section{Dear Sisters,}

I'm a 15 year old muslim feminist who finds it very hard to get hold of your magazine. My family doesn't approve of me 'wasting my money on useless junk'!! (as quoted from my dad!).

Anyway could you send me one latest copy of your fantastic mag.

Yours in sisterhood,

\section{A muslim feminist}

\section{Bristol.}

P.S. Does your magazine have a 'classified' column e.g. Penpals. I'm very lonely and frustrated 'cause I don't know any other Asian feminists (even my friends mock me!!). So here's hopefully. (I can’t wait for your mag!). (Mukti 4, 1985)

This isolated reader communicates with the magazine as if it were one of her friends, suggesting that it is through the acts of producing and consuming that the figure of the 


\section{Black Feminist Periodicals}

politically black woman was generated and circulated. Like the other periodicals examined in this article, Mukti strove to make links between race, class and gender oppression that both allowed them to provide a complex political analysis and create an oppositional identity of blackness that ethnic minority women could unite around.

For us, the issue of race affects every facet of our lives - Black women whose reality is about survival, not comfort/luxuries/ privileges. Even if we happen to have a 'real home', or hold down a 'decent' job what does it mean if at any moment, we and our children can and are killed (often with impunity) merely for being Black/alien/'other'. We run the continually terrifying risk of being 'punished', not just abused or maligned for being, for example, 'unemployed' or on-the-dole, but murdered for existing in this country. Any gains that we may appear to have are always precarious. There are no guarantees for Black women. (Mukti 4, 1985)

Nevertheless, the issue of differences between these different black groups in the movement was a preoccupation of the magazine, which was unsurprising given the liminal place that Asian women had always occupied in the black women's movement. Earlier in the 1980s, OWAAD had broken down in part over the issue of Afro-Asian unity (Brixton Black Women's Group, 1984). Indeed, the existence of Mukti itself points to the limits of blackness as a political formation, and to the ways in which the black women's movement could not always adequately cater for the specific needs of Asian women. Issue six, on racism and prejudice within the Asian community, proved particularly contentious when it discussed the sometimes difficult relationships between Asian and black communities, and, controversially, examined the ways in 


\section{Black Feminist Periodicals}

which middle-class Asian South Africans propped up apartheid through using black domestic labour (Mukti 6, 1987).

Mukti thus raised questions about how Asian women make a space for their own concerns within the black women's movement whilst remaining part of it. Could a viable black identity that did useful political work be founded simply on a collective opposition to the racist state? One contributor, Mumtaz Karimjee, discussed how she understood her own identity after contributing to an exhibition of photographs about Asian women:

The Black community in Britain is no [sic] monolithic, and while I consider myself part of the Black community, there are clearly occasions when the word Black does not include me - sometimes it means only African/Caribbean, at other times it includes those of us of Asian, i.e. South Asian, origin, but excludes others. For me, Black is a political term, which I use to explain my political position, not to explain my racial origins. I feel and continue to feel that I am Black in the context of the struggle of all nonwhite non-indigenous communities in this country regardless of their skin colour...(Karimjee, Mukti 6, 1987)

Such views attracted support from African and African-Caribbean women, though many felt unclear about the ways in which this could be articulated effectively in sensitive situations:

Should I intrude in this space that had been fought for and kept open by your committed collective? Should I write and give my views, shaped as they are 


\section{Black Feminist Periodicals}

within the context of my Black African/Caribbean experiences? Support was there for your journal but to openly express this in support and also criticism I was not too sure about. (Mukti 4, 1985)

This ultimately pointed to both the strength and fragility of political blackness as it was used and experienced day-to-day by actors in these social movements, as well as the shifting and unstable nature of it as a formulation. 'Blackness', as an idea, allowed Afro-Caribbean, African and South Asian women to come together, but it could also marginalize the experiences of Asian women, leading to dissent and factionalism.

\section{Conclusion}

By the end of the 1980s, both the Black and white women's movements had transformed out of all recognition from the early 1970s; many of the women involved in the movements were gloomy about the apparent downturn in activism that had taken place during this period. Prominent feminist activist Prathibha Parmar wrote of the black women's movement in 1989 that:

it seems difficult to fathom where the optimism and stridency which many of us had who were active in the black women's movement has gone, and why. Where are the diverse black feminist perspectives which we felt were in the process of growth? And where indeed is the movement itself?...Four years is not a long time, but it is obviously long enough to see the disintegration of what was once an energetic and active black women's movement (Parmar 1989: 55) 


\section{Black Feminist Periodicals}

Black women's periodicals mirrored this trajectory. By the late 1980s, without funding or the support of a wider vibrant women's movement to sustain them, they ran into the ground. Black feminist periodicals helped in the production of an imagined community of black feminism and provided a discursive arena that allowed for the development of theory and critique. They demonstrated the shift from a politics that was largely grounded in the Black radical movement of the 1960s and 1970s, which focused on the racist nature of the capitalist state, to a more recognizably feminist politics of the 1980s, which focused on the politics of the personal and was more comfortable using subjective experience as a base from which to build theory. Notably, it is clear that contemporary feminist debates about intersectionality have their origins in the project of black feminism during this period to understand the links between race, class and gender. In this way, Black women and the periodicals they produced played a vital role in the history of a movement whose influence on modern feminism has been profound.

\section{Works Cited}

Amos, Valerie, and Parmar, Pratibha (1984), 'Challenging imperial feminism', Feminist Review 17, 'Black Women Organising', pp. 3-19.

Bryan, Beverley, Dadzie, Stella, and Scafe, Suzanne (1985), The Heart of the Race: Black Women's Lives in Britain Today, London: Virago.

Crenshaw, Kimberle W. (1989) 'Demarginalizing the Intersection of Race and Sex: A Black Feminist Critique of Antidiscrimination Doctrine, Feminist Theory and Antiracist Politics, University of Chicago Legal Forum 139-67. Reprinted in The Politics of Law: A Progressive Critique 195-217 (2nd edn), ed. by David Kairys, Pantheon, 1990.

DiCenzo, Maria, with Leila Ryan and Lucy Delap (2010), Feminist Media History: 
Black Feminist Periodicals

Suffrage, Periodicals, and the Public Sphere, Basingstoke: Palgrave Macmillan.

Forster, Laurel (2015), Magazine Movements: Women's Culture, Feminisms and Media Form, London: Bloomsbury.

Fraser, Nancy (1992), 'Rethinking the Public Sphere: A Contribution to the Critique of Actually Existing Democracy' in Craig Calhoun (ed.) Habermas and the Public Sphere, Cambridge MA: MIT Press, pp. 109-42.

Modood, Tariq (1988), “"Black”, Racial Equality and Asian Identity”, New Community 14:3, pp. 397-404 (399).

Parmar, Pratibha (1989), 'Other Kinds of Dreams', Feminist Review 31 (Spring), pp. $55-65$.

Sudbury, Julia (1998), Other Kinds of Dreams: Black Women's Organisations and the Politics of Transformation, Abingdon: Routledge.

Tarrow, Sidney (1998), Power in Movement: Social Movements and Contentious Politics, $2^{\text {nd }}$ edn, Cambridge: Cambridge University Press.

Swaby, Nydia (2014), 'Disparate in voice, sympathetic in direction: gendered political blackness and the politics of solidarity', Feminist Review 108, pp.11-25.

Thomlinson, Natalie (2016), Race, Ethnicity and the Women's Movement in England, 1968 - 1993, Basingstoke: Palgrave.

Wild, Rosalind (2008), 'Black Was The Colour Of Our Fight: Black Power in Britain, 1955-1976', PhD thesis, University of Sheffield.

\section{Periodicals}

FOWAAD 1 (1979). 
Black Feminist Periodicals

FOWAAD 4 (1980)

'Workshop Report Back: Our Differences', We Are Here: Black Feminist Newsletter (old series, undated, c. 1984), unpaginated.

Editorial, We Are Here: Black Women's Magazine (new series) 1 (March 1988)

We Are Here: Black Women's Magazine 3 (undated, c. 1988).

Editorial collective, Mukti 7 (1987).

Anonymous, 'Me giving, you taking', Mukti 3 (Spring 1984).

Anonymous, Mukti 4 (Autumn 1984)

Mukti collective, 'We work all our lives, Mukti 4, Autumn 1985

Lorna, 'Maids and madams in the Natal community', Mukti 6 (Spring 1987).

Mumtaz Karimjee, 'Black and Asian: Definitions and Redefinitions' Mukti 6 (1986).

'Valerie', Mukti 4 (Autumn 1985).

Lee and K. Black, 'Womynism: is it Goodbye to 'Black Feminism?', We Are Here (old series), 5 March 1985.

Speak Out 4 (undated). 